\title{
Effect of zinc sources on milk yield, milk composition and plasma concentration of metabolites in dairy cows
}

\author{
S. Bakhshizadeh, F. Mirzaei Aghjehgheshlagh ${ }^{1 \#}$, A. Taghizadeh ${ }^{2}$, J. Seifdavati $^{1}$ \& B. \\ Navidshad ${ }^{1}$ \\ ${ }^{1}$ Department of Animal Sciences, Faculty of Agriculture, University of Mohaghegh Ardabili, Ardabil, Iran \\ ${ }^{2}$ Department of Animal Sciences, Faculty of Agriculture, University of Tabriz, Tabriz, Iran
}

(Received 1 October 2018; Accepted 5 September 2019; First published online 28 October 2019)

\author{
Copyright resides with the authors in terms of the Creative Commons Attribution 4.0 South African License. \\ See: http://creativecommons.org/licenses/by/4.0/za \\ Condition of use: The user may copy, distribute, transmit and adapt the work, but must recognise the authors and the South African \\ Journal of Animal Science
}

\begin{abstract}
This study was conducted to evaluate the effects of different sources of zinc (Zn) on feed intake, milk yield, milk composition, and blood metabolites. Twenty-four dairy cows were randomly allocated to one of four treatments in a randomized complete block design. The treatments consisted of i) control diet (no zinc supplementation), ii) zinc oxide ( $\mathrm{ZnO})$, iii) zinc glycine ( $\mathrm{ZnGly})$, and iv) zinc nano $(\mathrm{ZnN})$. The $\mathrm{Zn}$ sources were added to provide $60 \mathrm{mg}$ of supplemental $\mathrm{Zn}$ per $\mathrm{kg}$ diet. There were no differences in dry matter intake, milk yield, bodyweight, and body condition score of the cows between treatments. Zinc supplementation in the form of $\mathrm{ZnN}$ and $\mathrm{ZnGly}$ decreased somatic cell count compared with the other treatments. The superoxide dismutase and plasma $\mathrm{Zn}$ concentrations in the cows provided ZnGly and $\mathrm{ZnN}$ were greater than those in the $\mathrm{ZnO}$ and control groups. No difference was detected between groups in biochemical and haematological parameters, except that blood urea nitrogen concentrations of cows supplemented with ZnGly and ZnN were less than for the ZnO supplemented and control cows. The results showed that nano and organic Zn sources in the diet of dairy cows were more suitable than inorganic $\mathrm{Zn}$ as supplements for dairy cows.
\end{abstract}

Keywords: milk composition, milk production, metabolism, somatic cell count

\# Corresponding author: f_mirzaei@uma.ac.ir

\section{Introduction}

Zinc (Zn) is an essential trace mineral and plays an important role in DNA and RNA synthesis and replication and in cell proliferation (Cortinhas et al., 2012). NRC (2001) recommended that 40-60 mg of $\mathrm{Zn} / \mathrm{kg}$ should be included in the diet of lactating dairy cows. The role of $\mathrm{Zn}$ in maintaining the status of the immune system has been documented (Nocek et al., 2006). It has been suggested that Zn deficiency could result in increased somatic cell count $(\mathrm{SCC})$ and ultimately increase mastitis in dairy cows (Whitaker et al., 1997).

Krebs (1998) studied the effects of feeding organic sources of Zn, copper (Cu) and Selenium (Se) to dairy cows on antioxidant enzymes and SCC. They found that feeding these organic sources reduced the number of subclinical mastitis cases, but did not alter the concentrations of serum super oxide dismutase (SOD), glutathione peroxidase and ceruloplasmin. Zinc supplementation could also increase milk yield, live weight gain, and growth rate (Kellogg et al., 2004; Xu \& Wang, 2001). Nocek et al. (2006) reported increased milk production in animals that received diets containing organically complexed minerals or a mixture of inorganic and organic complexed minerals. Zinc supplementation may also enhance the disease resistance and nutritional quality of livestock products (Wright \& Spears, 2004; Tomlinson et al., 2004).

Supplemental $\mathrm{Zn}$ in rations for dairy cows is usually in the form of inorganic $\mathrm{Zn}$ (zinc oxide ( $\mathrm{ZnO}$ ) or zinc sulfate (ZnSO4)). Some studies reported that organic $\mathrm{Zn}$ is more readily absorbed by ruminants than inorganic Zn (Spears \& Weiss, 2008; Qin et al., 2007). Thus, use of trace elements from organic sources (that is, complexed chelated amino acids, proteinates), which are more bioavailable (Spears et al., 2004) compared with those from inorganic sources, can be nutritionally important for maximizing milk production and maintaining health. Recently, a novel source of elemental $\mathrm{Zn}$ has been used in animal diets. The development of nanotechnology has led to the creation of $\mathrm{Zn}$ nanoparticles $(\mathrm{ZnN})$ which have unique 
properties including great specific surface area, high surface activity, high catalytic efficiency, and strong absorbing ability (Kinal et al., 2005). The $\mathrm{ZnN}$ are a specially prepared mineral salt with a particle size of 1 to $100 \mathrm{~nm}$. The feeding of $\mathrm{ZnN}$ has been shown to have greater efficacy and reduced toxicity compared to conventional Zn sources (Wang et al., 2006). The sudden rise in demand for $\mathrm{ZnN}$ has been attributed to its superior antibacterial properties when compared to $\mathrm{Zn}$ from conventional sources (Padmavathy \& Vijayaraghavan, 2008). Dose-dependent effects of $\mathrm{ZnN}$ on growth performance have been observed in livestock and poultry (Hongfu, 2008; Mishra et al., 2014). It may also act as an antimicrobial and immunemodulatory agent in reducing the incidence of diarrhoea in piglets (Hongfu, 2008). Juncai \& Zhisheng (2011) reported that using $\mathrm{ZnN}$ in the diet of dairy cows improved rumen bacteria growth and increased the efficiency of energy utilization.

Thus, the objective of this study was to evaluate the effects of three sources of $\mathrm{Zn}$ on feed intake, milk yield, milk composition, plasma concentration of metabolites, and changes in body condition score (BCS) in lactating Holstein dairy cows.

\section{Materials and Methods}

The care and use of animals for this study was approved by the Animal Welfare Committee of the University of Mohaghegh-Ardabili. Twenty-four Holstein dairy cows (8 primiparous and 16 multiparous) were used in a 12-week study. Animals were blocked based on parity, and commenced the study at approximately 31 days (SD \pm 10.3 ) into lactation. The cows were housed in individual stalls with continual access to water. The basal diet was formulated according to NRC (2001). All cows received the same basal diet, which was predicted to supply $34 \mathrm{mg} / \mathrm{kg}$ DM of $\mathrm{Zn}$ per cow per day (Table 1 ). This diet was supplemented at a rate of $60 \mathrm{mg} \mathrm{Zn/kg} \mathrm{DM}$ with Zn in forms of zinc oxide (ZnO), zinc glycine (ZnGly) and ZnN (particle size >99\% 15$21 \mathrm{~nm}$ ). Therefore, the treatments consisted of i) the basal without further $\mathrm{Zn}$ supplementation; ii) the basal diet supplemented with $\mathrm{ZnO}$; iii) the basal diet supplemented with ZnGly (B-TRAXIM 2C, Transchem, Sydney, Australia); and iv) the basal diet supplemented with $\mathrm{ZnN}$.

Nanoparticles of $\mathrm{Zn}$ were prepared using the chemical co-precipitation method that was reported by Massart (1981). To prepare the $\mathrm{Zn}$ nano-composite, $3.21 \mathrm{~g}$ zinc nitrate $\left(\mathrm{Zn}\left(\mathrm{NO}_{3}\right)_{2}\right)$ was dissolved in $100 \mathrm{~mL}$ of water and mechanically stirred for $30 \mathrm{~min}$. An aqueous solution of $5 \mathrm{M}$ sodium hydroxide was then added dropwise and stirred into the room-temperature solution until the $\mathrm{pH}$ of the solution reached 10 . The suspension was then refluxed for $60 \mathrm{~min}$ at $96{ }^{\circ} \mathrm{C}$. The suspension was centrifuged ( $3000 \mathrm{rpm}, 5 \mathrm{~min}$ ) to remove the precipitate, washed twice with double distilled water and ethanol to remove the unreacted reagents, and dried in an oven at $60{ }^{\circ} \mathrm{C}$ for 24 hours. Scanning electron microscopy) was employed to determine the structure and morphology of the $\mathrm{Zn}$ nano-prepared samples (Jeol JSM-6060LV, Tokyo. Japan). The average $(n=9)$ particle size was 18 to $22 \mathrm{~nm}$.

Animals received the basal mix ration twice daily at $09 \mathrm{~h} 00$ and $14 \mathrm{~h} 00$ at the rate of $105 \%$ of the previous ad libitum daily intake. Orts were removed twice weekly and weighed. Feed samples were collected twice weekly and bulked every five weeks, with a representative subsample being sent to Direct Laboratories (Tabriz, Iran) for analysis.

Cows were milked twice daily at approximately $05 \mathrm{~h} 00$ and $17 \mathrm{~h} 00$. Milk yield was recorded automatically at each milking, and the composition of the milk from one 24-hour period was analysed weekly with additional samples being taken fortnightly for SCC. Samples for SCC determination were analysed within 24 hours (Direct Laboratories, Tabriz, IRAN). Body condition score was scored each week based on a 5-point scale with 0.25 intervals, where $1=$ thin and $5=$ fat (Lowman et al., 1976).

During weeks $0,4,8$, and 12 of the study, blood samples were collected two hours after the morning feeding via venipuncture from the jugular vein. Samples were collected into vacutainer tubes containing either sodium heparin or EDTA. After centrifugation at $3500 \times \mathrm{g}$ for $20 \mathrm{~min}$ at $4{ }^{\circ} \mathrm{C}$, the plasma was removed and stored at $-20^{\circ} \mathrm{C}$ for later determination of enzyme activity, $\mathrm{Zn}$ concentration and biochemical parameters. To determine the haematology profile of the whole blood, samples were collected in $\mathrm{Zn}$-free no-additive tubes, allowed to clot at ambient temperature $\left(15-21^{\circ} \mathrm{C}\right)$, centrifuged at $3500 \times \mathrm{g}$ for $10 \mathrm{~min}$, with the serum being analysed after two hours. White blood cell (WBC) count, red blood cell (RBC) count, haemoglobin concentration $(\mathrm{Hb})$, packed cell volume (PCV), mean corpuscular volume (MCV), mean corpuscular haemoglobin $(\mathrm{MCH})$, mean corpuscular haemoglobin concentration (MCHC), and number of platelets (PLT) were recorded with an automatic haematology cell counter (Celltak, NEK6108K, Istanbul, Turkey). Lactate dehydrogenase (LDH), alkaline phosphatase (ALP), super oxide dismutase (SOD), total protein (TP), glucose (GLU), blood urea nitrogen (BUN), total cholesterol (TC), triglyceride (TG), and albumin (ALB) contents of serum samples were determined, as were concentrations of high density lipoprotein (HDL) and low density lipoprotein (LDL) using commercial kits (Pars Azmoon kits, Pars Azmoon, Tehran, Iran) and the Chemistry analyser Dirui CS-400 (Changchun, China). 
Composition of the feedstuffs was determined using AOAC (1990) methods, namely dry matter (DM) (method 934.01), organic matter (OM) (method 942.01), Zn (method 969.32), and crude protein (CP) (method 954.01). Neutral detergent fibre (NDF) and acid detergent fibre (ADF) analyses were performed according to the methodology of Van Soest \& Mason (1991), using a-amylase without the addition of sodium sulfite when determining NDF. Milk samples were analysed for Zn content following Cope et al. (2009). Milk constituents were analysed using a Milko Scan (Ekomilk Total, Stara Zagora, Bulgaria).

Table 1 Composition of the basal diet that was fed to dairy cows to assess supplementation of zinc in various forms

\begin{tabular}{lc}
\hline Ingredient (g/kg of DM) & Amount \\
\hline Alfalfa hay & 143.9 \\
Corn silage & 281.2 \\
Wheat straw & 9.5 \\
Barley grain & 111.7 \\
Corn grain & 180.4 \\
Wheat bran & 31.3 \\
Sugar beet pulp & 36 \\
Molasses beet sugar & 12.7 \\
Fish meal & 26.9 \\
Extruded linseed & 25.2 \\
Soybean, meal & 88.4 \\
Soybean seeds, whole heated & 24.7 \\
Di-calcium phosphate & 2.1 \\
Calcium carbonate & 4.2 \\
Magnesium oxide & 2.9 \\
Salt & 4.2 \\
Sodium bicarbonate & 8.4 \\
Mineral and vitamin premix ${ }^{\mathrm{a}}$ & 6.3 \\
Chemical composition (g/kg of DM) & \\
Dry matter (DM) & 520 \\
Organic matter (OM) & 912 \\
Crude protein & 155 \\
Acid detergent fibre (ADF) & 19 \\
Neutral detergent fibre (NDF) & 315 \\
Net energy lactation (Mcal/kg of DM) & 1.61 \\
Zinc (mg/kg DM) & 34 \\
\hline
\end{tabular}

${ }^{\text {a} P r e m i x ~ c o m p o s i t i o n ~ p e r ~ k g: ~ C a: ~} 100$ g, P: 50 g, Na: 61 g, Mg: 17 g, Cu: 330 mg, Fe: 235 mg, Mn: 720 mg, l: 13 mg, Co: $6 \mathrm{mg}$, Se: $5 \mathrm{mg}$, vitamin A: 86,000 IU, vitamin D3: 20,000 IU, vitamin E: 770 IU

The serum Zn concentration was determined according to the method reported by Fick et al. (1979). Briefly, $10 \mathrm{ml}$ nitric acid was added to $4 \mathrm{ml}$ of plasma and the mixture was heated for 15 minutes at $45^{\circ} \mathrm{C}$, then $5 \mathrm{ml}$ of concentrated nitric acid was added, and the mixture was heated to $45^{\circ} \mathrm{C}$ for an additional 30 minutes. This step was repeated twice. Then $5 \mathrm{ml}$ hydrochloric and $10 \mathrm{ml}$ distilled water were added. This mixture was increased in volume to $50 \mathrm{~mL}$ by adding more distilled water filtered through a Whatman No 42 paper. The concentration of $\mathrm{Zn}$ in the solution was measured with a flame atomic absorption spectrophotometer (spectrAA220Variant, Perth, Australia).

The data were analysed using PROC MIXED of SAS (2002) for a randomized complete block design with repeated measurements. The variance among animals within treatment was regarded as a random error to test treatment effects. Initial values for recorded traits were considered covariates in the repeated measures model. Thus, the linear model was: 


$$
y_{i j k l}=\mu+b_{i}+t_{j}+\operatorname{cow}_{k(i j)}+p_{l}+t p_{j l}+e_{i j k l}
$$

where: $y_{i j k l}=$ an observation from the from the $\mathrm{k}^{\text {th }}$ cow in the $\mathrm{i}^{\text {th }}$ block $\left(b_{i}\right)$ that was subjected to the $\mathrm{j}^{\text {th }}$ treatment $\left(t_{j}\right) ; \mu=$ the mean which was common to all observations; $p_{l}=$ the $\mathrm{I}^{\text {th }}$ time at which the observation was recorded; $t p_{j l}=$ the interaction of treatment and time; and $e_{i j k l}=$ the residual variation within animals, which served as error for the effects of time and the interaction of treatment with time. Differences between means were tested using the LSMEANS statement in SAS.

\section{Results}

No effects of $\mathrm{Zn}$ source or the interaction of $\mathrm{Zn}$ source and time on DMI, milk yield, and milk composition were detected (Table 2). However, there were significant effects of time on DMI and milk yield, with an increase in milk yield being observed from the third to the eighth week of lactation. The concentration of $\mathrm{Zn}$ in milk did not differ between dietary treatments. Cows that received ZnGly and $\mathrm{ZnN}$ had reduced $(P$ $<0.05)$ SCC compared with those fed the control and ZnO diets. Somatic cell count decreased as lactation progressed $(P<0.05)$. Effects of zinc source, time, and the interaction of $\mathrm{Zn}$ source and time on BW and BCS were not detected.

Table 2 Effects of the form of zinc in supplements provided to Holstein dairy cows on feed intake and milk production

\begin{tabular}{|c|c|c|c|c|c|c|c|c|}
\hline \multirow{2}{*}{ Traits $^{2}$} & \multicolumn{4}{|c|}{ Treatment $^{1}$} & \multirow{2}{*}{ SEM } & \multicolumn{3}{|c|}{ Probability } \\
\hline & $\mathrm{C}$ & $\mathrm{ZnO}$ & ZnGly & $\mathrm{ZnN}$ & & Source & Time & Source $\times$ Time \\
\hline DMI (kg/d) & 22.8 & 22.8 & 23.2 & 23.6 & 0.2 & 0.39 & 0.01 & 0.63 \\
\hline Milk yield, (kg/d) & 37.9 & 37.3 & 38.7 & 38.2 & 0.4 & 0.07 & $<0.01$ & 0.76 \\
\hline Fat $(\mathrm{g} / \mathrm{kg})$ & 30.1 & 30.5 & 30.1 & 30.1 & 0.3 & 0.76 & 0.87 & 0.57 \\
\hline Fat $(\mathrm{kg} / \mathrm{d})$ & 1.14 & 1.14 & 1.162 & 1.15 & 1.41 & 0.60 & 0.13 & 0.45 \\
\hline Protein $(\mathrm{g} / \mathrm{kg})$ & 30.6 & 31.0 & 31.9 & 31.1 & 0.6 & 0.09 & 0.95 & 0.28 \\
\hline Protein (kg/d) & 1.16 & 1.16 & 1.23 & 1.19 & 1.56 & 0.49 & 0.17 & 0.29 \\
\hline Lactose (g/kg) & 45.7 & 46.3 & 45.9 & 45.5 & 0.38 & 0.49 & 0.08 & 0.29 \\
\hline Lactose (kg/d) & 1.73 & 1.73 & 1.78 & 1.74 & 2.30 & 0.41 & 0.37 & 0.23 \\
\hline Zn (mg/kg) & 3.07 & 3.07 & 3.13 & 3.18 & 0.08 & 0.70 & 0.24 & 0.34 \\
\hline $\operatorname{SCC}\left(10^{3} / \mathrm{ml}\right)$ & $153.7^{b}$ & $150.0^{b}$ & $142.5^{\mathrm{a}}$ & $140.2^{\mathrm{a}}$ & 1.5 & 0.01 & $<0.01$ & 0.12 \\
\hline SNF (g/kg) & 80.3 & 79.5 & 78.8 & 78.1 & 0.5 & 0.04 & 0.75 & 0.87 \\
\hline $\operatorname{SNF}(\mathrm{kg} / \mathrm{d})$ & 3.05 & 3.00 & 2.81 & 3.05 & 2.99 & 0.32 & 0.13 & 0.29 \\
\hline BW ( kg) & 632 & 642 & 641 & 638 & 6 & 0.67 & 0.12 & 0.23 \\
\hline${ }^{1} \mathrm{BCS}$ & 3.31 & 3.32 & 3.24 & 3.26 & 0.42 & 0.73 & 0.10 & 0.37 \\
\hline
\end{tabular}

${ }^{1} \mathrm{C}$ : control; ZnO: zinc oxide supplement, ZnGly: zinc glycine supplement; ZnN: zinc nanoparticle supplement

${ }^{2}$ DMI: dry matter intake; Zn: zinc; SCC: somatic cell count; SNF: solids not fat; BW: bodyweight; BCS: body condition score, recorded on a 5-point scale (Lowman et al., 1976) with 0.25 intervals, where $1=$ thin and $5=$ fat

${ }_{\mathrm{a}, \mathrm{b}}$ Within a row, means without a common superscript letter differ with $P<0.05$

The results of the haematological characterization are shown in Table 3 . There was no significant effect of time, treatment, or time and treatment interaction on red and white blood cell-related variables. The activity of SOD was greater for cows that were supplemented with ZnN and ZnGly than for those fed the basal diet alone or supplemented with $\mathrm{ZnO}(P<0.05)$. Differences between treatments were not detected for ALP, TP, GLU, ALB, TG, TC, HDL, and LDL. However, BUN concentration in plasma decreased with ZnN and ZnGly supplementation $(P<0.05)$. The $Z n$ serum concentrations of $Z n$ were greater for cows that were supplemented with $\mathrm{ZnN}$ and ZnGly compared with those that were supplemented with $\mathrm{ZnO}$ and those fed the basal diet $(P<0.01)$. Highly significant effects of time, which affected $Z n$ concentration in plasma, were also observed, as were similarly significant effects on all of the indicators of metabolic status. 
Table 3 Effects of the form of zinc in supplements provided to Holstein dairy cows on haematology, serum enzyme activities and indicators of metabolic status in dairy cows

\begin{tabular}{|c|c|c|c|c|c|c|c|c|}
\hline \multirow{2}{*}{ Trait $^{2}$} & \multicolumn{4}{|c|}{ Treatments $^{1}$} & \multirow{2}{*}{ SEM } & \multicolumn{3}{|c|}{ Probability } \\
\hline & $\mathrm{C}$ & $\mathrm{ZnO}$ & ZnGly & $\mathrm{ZnN}$ & & source & Time & Source $\times$ Time \\
\hline WBC $\left(10^{3} / \mathrm{ml}\right)$ & 8.59 & 8.77 & 9.09 & 8.85 & 0.17 & 0.22 & 0.32 & 0.07 \\
\hline Lymphocytes $\left(10^{3} / \mathrm{ml}\right)$ & 2.36 & 2.33 & 2.32 & 2.23 & 0.06 & 0.40 & 0.25 & 0.06 \\
\hline Monocytes $\left(10^{3} / \mathrm{ml}\right)$ & 0.51 & 0.62 & 0.74 & 0.78 & 0.06 & 0.22 & 0.69 & 0.99 \\
\hline Granulocytes $\left(10^{3} / \mathrm{ml}\right)$ & 5.74 & 5.78 & 5.95 & 5.72 & 0.12 & 0.56 & 0.48 & 0.33 \\
\hline $\operatorname{RBC}\left(10^{6} / \mathrm{mm}^{3}\right)$ & 6.13 & 6.14 & 6.09 & 6.11 & 0.03 & 0.94 & 0.22 & 0.79 \\
\hline HGB $(g / d l)$ & 9.18 & 9.21 & 9.16 & 9.16 & 0.03 & 0.44 & 0.06 & 0.72 \\
\hline HCT (\%) & 28.1 & 28.9 & 28.1 & 28.1 & 0.1 & 0.81 & 0.33 & 0.79 \\
\hline $\operatorname{PLT}\left(10^{3} / \mathrm{mm}^{3}\right)$ & 452 & 434 & 430 & 442 & 12 & 0.59 & 0.34 & 0.31 \\
\hline $\operatorname{MCV}(\mathrm{fl})$ & 46.0 & 46.0 & 46.1 & 46.0 & 0.1 & 0.98 & 0.07 & 0.65 \\
\hline $\mathrm{MCH}(\mathrm{pg})$ & 15.0 & 15.1 & 15.0 & 15.0 & 0.1 & 0.75 & 0.27 & 0.85 \\
\hline $\mathrm{MCHC}(\mathrm{g} / \mathrm{dl})$ & 32.6 & 32.8 & 32.6 & 32.7 & 0.1 & 0.36 & 0.20 & 0.56 \\
\hline Lactatedehydrogenas (IU/I) & 1796 & 1812 & 1835 & 1827 & 15 & 0.99 & 0.02 & 0.81 \\
\hline Super oxide dismutase (IU/I) & $2146^{\mathrm{b}}$ & $2149^{b}$ & $2170^{\mathrm{a}}$ & $2187^{\mathrm{a}}$ & 13 & 0.02 & 0.01 & 0.08 \\
\hline Alkaline phosphatase (IU/I) & 107.3 & 108.1 & 109.2 & 108.3 & 0.82 & 0.44 & 0.001 & 0.74 \\
\hline Cholesterol (mg/dl) & 259.8 & 258.4 & 258.4 & 258.1 & 1.1 & 0.68 & $<0.001$ & 0.79 \\
\hline Triglyceride (mg/dl) & 16.21 & 16.48 & 16.04 & 15.98 & 0.52 & 0.34 & $<0.001$ & 0.002 \\
\hline High density lipoprotein (mg/dl) & 135.4 & 134.4 & 134.9 & 133.9 & 0.7 & 0.46 & $<0.001$ & 0.38 \\
\hline Low density lipoprotein (mg/dl) & 130.1 & 126.8 & 128.1 & 129.7 & 1.5 & 0.40 & $<0.001$ & 0.0398 \\
\hline Blood urea nitrogen $(\mathrm{mg} / \mathrm{dl})$ & $17.0^{\mathrm{a}}$ & $16.5^{\mathrm{a}}$ & $15.9^{\mathrm{b}}$ & $15.5^{\mathrm{b}}$ & 0.3 & 0.006 & $<0.001$ & 0.15 \\
\hline Albumin (mg/dl) & 3.53 & 3.48 & 3.76 & 3.83 & 0.15 & 0.32 & $<0.001$ & 0.16 \\
\hline Glucose (mg/dl) & 57.8 & 57.6 & 57.8 & 56.9 & 0.5 & 0.59 & $<0.001$ & 0.08 \\
\hline Total protein (mg/dl) & 6.48 & 6.66 & 6.62 & 6.59 & 0.12 & 0.73 & $<0.001$ & 0.57 \\
\hline $\operatorname{zinc}(\mu \mathrm{g} / \mathrm{ml})$ & $1.21^{\mathrm{b}}$ & $1.83^{\mathrm{b}}$ & $2.45^{\mathrm{a}}$ & $2.33^{\mathrm{a}}$ & 1.05 & 0.002 & 0.006 & 0.88 \\
\hline
\end{tabular}

${ }^{1} \mathrm{C}$ : control; ZnO: zinc oxide supplement, ZnGly: zinc glycine supplement; ZnN: zinc nanoparticle supplement

${ }^{2} \mathrm{HGB}$ : haemoglobin concentration; HCT: haematocrit; MCH: mean corpuscular haemoglobin; MCHC: mean corpuscular haemoglobin concentration; MCV: mean corpuscular volume; PCV: packed cell volume; PLT: platelet concentration; RBC: red blood cell count; WBC: white blood cell count

${ }_{a, b}$ Within a row, means without a common superscript letter differ at $P<0.05$

The interaction of $\mathrm{Zn}$ sources and time affected concentrations of LDL and TG in the plasma (Table 4). The concentration of $L D L$ in plasma was reduced $(P<0.05)$ in weeks 8 and 12 in the cows that received ZnGly and ZnN compared with those that were fed the $\mathrm{C}$ diet. In comparison with the cows fed the basal diet, plasma TG concentration were significantly decreased in cows that received the ZnGly and $\mathrm{ZnN}$ supplements from week 4 to week 12. Cows that were supplemented with $\mathrm{ZnO}$ had reduced plasma triglyceride levels only at weeks 8 and 12 , compared with the $C$ diet. 
Table 4 Effects of the interaction between the form of zinc in supplements provided to Holstein dairy cows and week of lactation on serum triglyceride and serum low density lipoprotein concentrations $(\mathrm{mg} / \mathrm{dl})$

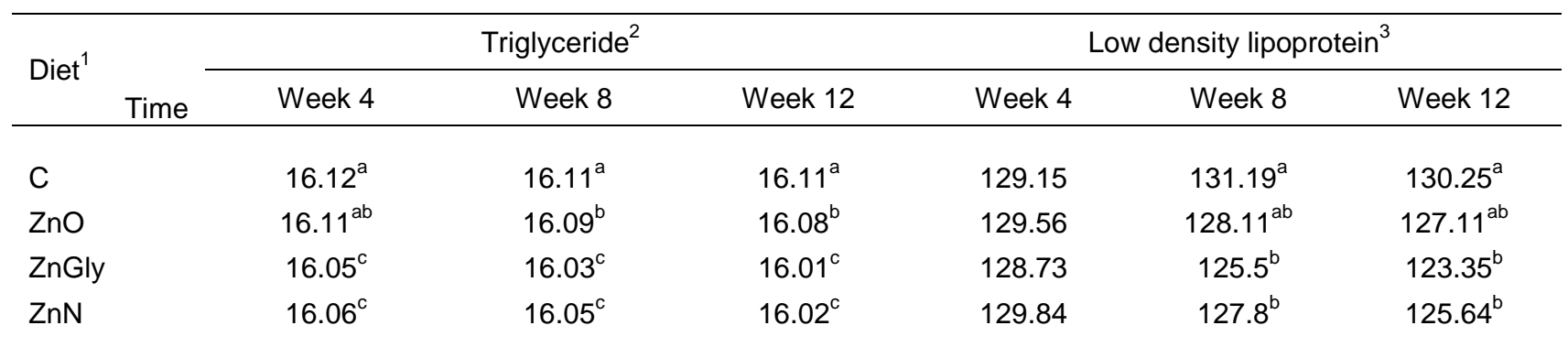

${ }^{1} \mathrm{C}$ : control; ZnO: zinc oxide supplement, ZnGly: zinc glycine supplement; ZnN: zinc nanoparticle supplement

${ }^{2} \mathrm{SEM}=0.11, P=0.002$

${ }^{3} \mathrm{SEM}=0.908, P=0.040$

$\mathrm{a}, \mathrm{b}, \mathrm{c}$ Within a variable means without a common superscript letter differ at $P<0.05$

\section{Discussion}

The failure of supplemental $\mathrm{Zn}$ to affect DMI that was observed in the current study is in contrast with the results of Miller et al. (1985), who reported that increasing Zn concentrations reduced the DMI of lactating dairy cows. As in previous studies, DMI increased through early lactation. After calving, voluntary feed intake increases rapidly due to the rise in demand for nutrients that are targeted for lactation (Cortinhas et al., 2012). Grant et al. (1995) also found that the DMI increased approximately 1.5 to $2.5 \mathrm{~kg} /$ week during the first three weeks of lactation.

Previously reported effects of types of trace mineral supplementation on milk yield are variable. Kinal et al. (2005) and Cope et al. (2009) reported an increase in milk production of dairy cows by feeding diets that contained organically complexed minerals or a mixture of inorganic and organically complexed minerals. Rajerden et al. (2013) supplemented Holstein Friesian crossbred cows with nano-zinc oxide and observed that milk yield increased compared with control. However, some studies (Campbell et al., 1999; Uchida et al., 2001) found that the form of supplemental $Z n$ had no effect on milk yield, in agreement with the results of the current study. In the present study, milk composition was not affected by various forms of $\mathrm{Zn}$ in the diet, verifying the reports of Cope et al. (2009) and Nocek et al. (2006). The form of $\mathrm{Zn}$ had no effect on the concentration of $\mathrm{Zn}$ in milk, either, which is consistent with the results of Nocek et al. (2006). The concentration of $\mathrm{Zn}$ in milk was also found to be constant with varying concentrations of dietary $\mathrm{Zn}$ (Cope et al., 2009). It has been suggested that $\mathrm{Zn}$ flux in the mammary gland of dairy cows is strictly regulated to maintain an adequate supply of $Z n$ to the neonate (Kelleher \& Lönnerdal, 2005).

The increase in the SCC for cows that received low levels of Zn may be attributed to a decrease in leukocyte function, which can lead to an increase in the susceptibility of the mammary gland to bacterial infection (Song et al., 2010). Here, cows that were fed the ZnGly and ZnN diets had reduced SCC concentrations compared with those fed control and $\mathrm{ZnO}$ diets. The antimicrobial properties of $\mathrm{ZnN}$ nanoparticles are associated with their specific high surface, area to volume ratio, and shape and size of particles (Arabi et al., 2012; Auffan et al., 2009). Tong et al. (2013) suggested that the size of 1-100 nm Zn nanoparticles could increase their antimicrobial activity owing to exposure of the polar surface plane of $\mathrm{ZnO}$ to the negatively charged bacterial cell membrane. Given the size of $\mathrm{Zn}$ nanoparticles that were used in present study (15-21 nm), low SCC was expected for cows that received the $\mathrm{ZnN}$ treatment. The addition of Zn nanoparticles has been reported to generate reactive oxygen species causing oxidative stress to bacterial cells (Feris et al., 2010; Kumar et al., 2011). Additionally, Zn nanoparticles may cause electrostatic disruption of the outer membrane and interruption of normal cell membrane functionality, resulting in the leakage of intracellular materials (Liu et al., 2009). The solubility of Zn may also affect metabolic activity and inhibit the growth of bacterial cells (Song et al., 2010). The results of the current study agreed with the findings of Rajerden et al. (2013) and Kinal et al. (2005), who recorded decreased SCC when cows were fed nano and organic chelated Zn, respectively. In contrast, Cope et al. (2009) observed no effect of Zn form on the SCC of dairy cows. However, Cope et al. (2009) had lower initial SCC, (means $\approx 130000 \mathrm{cells} / \mathrm{mL}$ ) compared with the present study (mean $=152,000 \mathrm{cells} / \mathrm{mL}$ ). Thus, it can be speculated that the initial level of SCC may be an important factor in beneficial effects from supplemental inorganic or organic $\mathrm{Zn}$.

In agreement with Cope et al. (2009), who supplemented $\mathrm{Zn}$ at $66 \%$ and $100 \%$ of the recommended level (NRC, 2006), the form of dietary Zn had no effect on BW or BCS. Whitaker et al. (1997) and Uchida et al., 2001 found that the form of Zn supplemented to the diet did not appear to affect BW or BCS in dairy 
cows, respectively. Similarly, Nocek et al. (2006) reported no significant effects on BW or BCS when inorganic Zn or organically chelated Zn was supplemented to cows.

In the present study, the form of dietary $Z n$ had no effect on blood haematology. However, the activity of SOD in cows supplemented with $\mathrm{ZnGly}$ and $\mathrm{ZnN}$ was greater than was found in the cows that were fed the basal diet or were supplemented with ZnO. Similarly, when Xu \& Wang (2001) supplemented pigs with 3000 $\mathrm{mg} \mathrm{Zn} \mathrm{oxide/kg} \mathrm{diet} \mathrm{activity} \mathrm{of} \mathrm{the} \mathrm{SOD} \mathrm{enzyme} \mathrm{increased} \mathrm{compared} \mathrm{with} \mathrm{pigs} \mathrm{that} \mathrm{were} \mathrm{fed} \mathrm{a} \mathrm{control} \mathrm{diet.}$

In this study, plasma BUN concentration decreased with ZnGly and $\mathrm{ZnN}$ supplementation. These results are consistent with Shakweer et al. (2010) and Shakweer et al. (2005), who found that Friesen calves whose diets were supplemented with zinc sulphate or zinc methionine at $45 \mathrm{mg} / \mathrm{kg} \mathrm{DMI}$ had decreased serum urea concentration. There were no significant effects of dietary treatment on plasma concentrations of GLU, TP, ALB, TG, TC, HDL, and LDL. Sobhanirad et al. (2009) did not find any effects of organic and inorganic $\mathrm{Zn}$ supplementation on indicators of metabolic status. The absence of treatment effects on these indicators implies that $\mathrm{Zn}$ supplements do not influence synthesis of protein and fat metabolism in animals (Cortinhas et al., 2012). However, the observed time effects that showed increased concentrations of TC, $\mathrm{HDL}, \mathrm{GL}$, and TP, and gradual reductions in concentrations of TG, BUN, and ALB during lactation may be associated with physiological processes that were concurrent with the experiment.

Kinal et al. (2005) and Spears et al. (2008) reported an increase in blood plasma Zn when animals were supplemented with organically chelated minerals compared with those fed inorganic (sulphate) minerals. Their results are consistent with data obtained in the current study. However, Cope et al. (2009) reported no change in plasma $\mathrm{Zn}$ concentration in dairy cows that were fed diets supplemented with organic and inorganic $\mathrm{Zn}$. Therefore, since blood $\mathrm{Zn}$ concentration is a common $\mathrm{Zn}$ index in the clinical field, increased concentration in the blood may be deemed a suitable tool to evaluate the $\mathrm{Zn}$ status of the body.

\section{Conclusion}

In general, supplementation of $\mathrm{Zn}$ in organic, inorganic and nano forms had no significant effect on DMI, milk yield, milk composition and blood haematology in early lactation cows. These data indicate reduced SCC in milk of animals that were supplemented with ZnGly and ZnN. This decreased in the SCC of milk confirms the antimicrobial properties organic and nano treatments.

\section{Acknowledgements}

The authors gratefully thank the staff of Mohaghegh Ardabili University and Tabriz University of Animal Science for their excellent assistance with this research.

\section{Authors' Contributions}

SB collected the data and FM drafted the manuscript. AT designed the study, JS and BN analysed the data. All authors approved the final manuscript.

\section{Conflict of Interest Declaration}

The authors have no financial, personal or other relationships with other people or organizations that could inappropriately influence or perceived to influence their work.

\section{References}

AOAC., 2005. Official method of analysis. Arlington, VA, US.

Arabi, F., Imandar, M., Negahdary, M., Noughabi, M.T. \& Akbari-Dastjerdi, H., 2012. Investigation anti-bacterial effect of zinc oxide nanoparticles upon life of Listeria monocytogenes. J. Ann Biol. Res.3, 3679-3685.

Auffan, M., Rose, J., Bottero, J., Lowry, G.V., Jolivet, J.P. \& Wiesner, M.R., 2009. Towards a definition of inorganic nanoparticles from an environmental, health and safety perspective. J. Nat. Nano tech.4, 634-641.

Campbell, M.H., Miller, J.K. \& Schrick, F.N.,1999. Effect of additional cobalt, copper, manganese, and zinc on reproduction and milk yield of lactating dairy cows receiving bovine somatotropin. J. Dairy. Sci. 82, 1019-1025.

Cope, C.M., Mackenzie, A.M., Wilde D. \& Sinclair L.A., 2009. Effects of level and form of dietary zinc on dairy cow performance and health. J. Dairy. Sci. 92, 2128-2135.

Cortinhas, C.S., Botaro, B.G. \& Sucupira, M.C.A., 2012. Antioxidant enzymes and somatic cell count in dairy cows fed with organic source of zinc, copper and selenium. J. Live st. Sci. 127, 84-87.

Feris, K., Otto C., Tinker, J., Wingett, D., Punnoose, A., ..., Pink, D., 2010. Electrostatic interactions affect nanoparticle mediated toxicity to gram-negative bacterium Pseudomonas aeruginosa PAO1. J. Langmui. 26 (6), 4429-4436.

Fick, K.R., McDowell, L.R., Miles, P.H., Wilkinson, N.S., Funk, J.D. \& Conrad. J.H. 1979. Methods of mineral analysis for plant and animal tissues. (2nd edition.) Animal Science Department, University of Florida, Gainesville.

Grant, R.J. \& Albright, J.L., 1995. Feeding behavior and management factors during the transition period in dairy cattle. J. Anim.Sci. 73, 2791-2803.

Hongfu, Y.B.Z., 2008. Effects of Nano ZnO on growth performance and diarrhea rate in weaning piglets. J. China Feed.1,1-8. 
Juncai, C. \& Zhisheng, W.W., 2011. Effect of nano-zinc oxide supplementation on rumen fermentation in vitro. Chin. J. Anim. Nut. 23, 1415-1421.

Kelleher, S.L. \& Lönnerdal B., 2005. Molecular regulation of milk trace mineral homeostasis. J. Aspect. Med. 26, 328339.

Kellogg, D. W., Tomlinson, D.J., Socha, M.T. \& Johnson, A.B., 2004. Review: Effects of zinc methionine complex on milk production and somatic cell count of dairy cows: Twelve-trial summary. J. Prof. Anim. Sci. 20, 295-301.

Kinal, S., Korniewiez, A., Jamroz, D., Zieminski, R. \& Slupezynska, M., 2005. Dietary effects of zinc, copper and manganese chelates and sulphates on dairy cows. J. Food. Agri. Environ. 3,168-172.

Krebs, N.F., 1998. Zinc supplementation during lactation. J. Clin. Nutr. 68, 509-512.

Kumar, A., Pandey, A.K., Singh, S.S., Shanker, R. \& Dhawan, A., 2011. Engineered ZnO and TiO2 nanoparticles induce oxidative stress and DNA damage leading to reduced viability of Escherichia coli. Free Radic. J. Bio. Med. 51, 1872-1881.

Liu, Y., He, L., Mustapha, A., Li, H., Hu, Z.Q. \& Lin, M., 2009. Antibacterial activities of zinc oxide nanoparticles against Escherichia coli O157:H7. J. Applied. Microbio. 107, 1193-1201.

Malcolm-Callis, K.J., Duff, G.C., Gunter, S.A., Kegley, E.B. \& Vermeire, D.A., 2000. Effects of supplemental zinc concentration and source on performance, carcass characteristics, and serum values in finishing beef steers. $J$. Anim. Sci. 78, 2801-2808.

Manson, R.J. \& Leaver, J.D., 1988. The influence of concentrate amount on locomotion and clinical lameness in dairy cattle. J. Anim. Prod. 47, 185-190.

Massart, R., 1981. Preparation of aqueous magnetic liquids in alkaline and acidic media. IEEE. J. Trans. Magan. $17,1247-1248$.

Miller, W.J., Amos, H.E., Gentry, R.P., Blackmon, D.M., Durrance, R.M., Crowe, C.T., Fielding, A.S. \& Neathery, M.W., 1989. Long-term feeding of high zinc sulfate diets to lactating and gestating dairy cows. J. Dairy Sci. 72, 14991508.

Mishra, A., Swain, R.K., Mishra, S.K., Panda, N. \& Sethy, K., 2014. Growth performance and serum biochemical parameters as affected by nano zinc supplementation in layer chicks. Indian. J. Anim. Nutr.31,384-388.

Nocek, J.E., Socha, M.T. \& Tomlinson, D.G., 2006. The effect of trace mineral fortification level and source on performance of dairy cattle. J. Dairy. Sci. 89, 2679-2693.

NRC., 2001. Nutrient requirements of dairy cattle. (7th ed.) National Academy Press, Washington, DC.

Padmavathy, N. \& Vijayaraghavan, R., 2008. Enhanced bioactivity of ZnO nanoparticles an antimicrobial study. J. Sci Technol. Adv. Mater. 9,1-7.

Qin, S., Gao, J. \& Huang, K., 2007. Effects of different selenium sources on tissue selenium concentrations, blood GSHPx activities and plasma interleukin levels in finishing lambs. J. Bio. Trace. Elem. Res. 116, 91-102.

Rajendran, D., Kumar, G., Ramakrishnan, S. \& Thomas, K.S., 2013. Enhancing the milk production and immunity in Holstein Friesian crossbred cow by supplementing novel nano zinc oxide. J. Res. Bio. 8, 11-17.

SAS Inc., 2002. SAS user's guide: Statistics. Statistical Analysis Systems Institute Inc., Cary, NC.

Shakweer I.M.E., EL-Mekass A.A.M. \& EL-Nahas H.M., 2010. Effect of zinc supplementations as zinc sulfate or zinc methionin on Friesian calf performance. Egyptian J. Anim. Prod. 47(1), 23-63.

Shakweer, I.M.E., EL-Mekass, A.A.M. \& EL-Nahas H.M., 2005. Effect of different levels of supplemented organic zinc source on performance of Friesian dairy cows. J. Agric. Sci. Mansoura Univ., 30(6), 3025-3035.

Sirelkhatim, A., Mahmud, S., Seeni, A., Kaus, N.H.M., Ann, L.C., Bakhori, S.K.M., Hasan, H. \& Mohaman, D., 2015. Review on zinc oxide nanoparticles: antibacterial activity and toxicity mechanism. J. Nano. Micro. Lett. 7, $219-242$.

Sobhanirad, S., Carlson, D. \& Bahari-Kashani, R., 2009. Effect of zinc methionine or zinc sulfate supplementation on milk production and composition of milk in lactating dairy cows. J. Bio. Trace. Elem. Res. 136, 48-54.

Song, W., Zhang, J., Guo, J., Zhang, J., Ding, F., Li, L. \& Sun, Z., 2010. Role of the dissolved zinc ion and reactive oxygen species in cyto-toxicity of ZnO nanoparticles. J. Toxi. Lett. 199(3), 389-397.

Spears, J.W. \& WEISS, W.P., 2008. Role of antioxidants and trace elements in health and immunity of transition dairy cows. J. Vet. Res. 176, 70-76.

Spears J.W., Schlegel, P., Seal, M.C. \& Lloyd, K.E., 2004. Bioavailability of zinc from zinc sulfate and different organic zinc sources and their effects on ruminal volatile fatty acid proportions. J. Livestock Pro.Sci.90, 211-217.

Tomlinson, D.J., Mulling, C.H.T. \& Fakler, M., 2004. Invited Review: Formation of keratins in the bovine claw: Roles of hormones, minerals and vitamins in functional claw integrity. J. Dairy. Sci. 87, 797-809.

Tong, G.X., Du, F.F., Liang, Y., Hu, Q., Wu, R.N., Guan, J.G. \& Hu, X., 2013. Polymorphous ZnO complex architectures: selective synthesis, mechanism, surface area and Zn-polar plane-codetermining antibacterial activity. J. Material. Chem. 4, 454-463.

Uchida, K., Mandebvu, P., Ballard, C.S., Sniffen, C.J. \& Carter, M.P., 2001. Effect of feeding a combination of zinc, manganese and copper amino acid complexes, and cobalt glucoheptonate on performance of early lactation high producing dairy cows. J. Anim. Feed. Sci. Technol. 93,193-203.

Wang, B., Feng, W.Y., Wang, T.C., Jia, G., Wang, M., .., Chai, Z.F., 2006. Acute toxicity of nano and micro-scale zinc powder in healthy adult mice. J. Toxicol. Lett.161,115-123.

Whitaker, D.A., Eayres, H.F., Aitchison, K. \& Kelly, J.M., 1997. No effect of a dietary zinc proteinate on clinical mastitis, infection rate, recovery rate and somatic cell count in dairy cows. J. Vet. Res. 153, 197-204.

Wright, C.L. \& Spears, J.W., 2004. Effect of zinc source and dietary level on zinc metabolism in Holstein calves. J. Dairy. Sci. 87, 1085-1091.

Xu, Z.R. \& Wang, M.Q., 2001. Approach of the mechanism of growth promoting effect of pharmacological level of zinc in pigs. J. Acta. Vet. Zootech. 32, 11-17. 